\title{
由良川河口部の砂州の形成・発達過程に関する 現地観測とその数値解析 \\ FIELD AND NUMERICAL STUDIES FOR FROMATION OF SAND BAR AT THE YURA RIVER MOUTH
}

\author{
中村文則 1 - 朝倉実里 2 -神田佳一 $3 \cdot$ 三輪 浩 4 ・細山田 得三 5 \\ Fuminori NAKAMURA, Misato ASAKURA, Keiichi KANDA, Hiroshi MIWA \\ and Tokuzou HOSOYAMADA
1正会員 博(工) 明石高専助教 都市システム工学科（†674-8501 兵庫県明石市魚住町西岡679-3）
2明石高専 建築・都市システム工学専攻（†674-8501 兵庫県明石市魚住町西岡679-3）
3 正会員 工博 明石高専教授 都市システム工学科（テ674-8501 兵庫県明石市魚住町西岡679-3）
4正会員 工博 舞鶴高専教授 建設システム工学科（干625-8511 京都府舞鶴市字白屋234）
5 正会員 工博 長岡技術科学大学教授 環境・建設系 （†940-2188 新潟県長岡市上富岡町1603-1）

\begin{abstract}
The elucidation of the developing process of sand bar in the river mouth is important for river management. In this study, in order to clarify the developing process of sand bars in the Yura river mouth located in Fukuchiyama city in Japan, the field measurements of sand bar form were carried out. Numerical simulation were also carried out using a series of two-dimensional model of wave and bed material load. In those results, the numerical results for the developing process of sand bar agree well with the field measurement results, and the developing process of sand bar at the Yura river mouth was evaluated by results of numerical simulation and field measurements.
\end{abstract}

Key Words : Yura river, Sand bar, River mouth, Numerical simulation, Boussinesq equations, Sediment transport

\section{1. はじめに}

日本海沿岸では，冬期の季節風の作用により激しい波 浪が来襲し，その影響を受け河口部に砂州が形成される. 一方，夏期では，冬期に形成された砂州が出水によって フラッシュされ, 砂州の形成・発達と消失が規則的に繰 り返される. 特に，冬期に形成・発達する河口砂州は， 出水期に河川の流れを阻害し，その周辺および上流にお いて水位上昇を引き起こす要因となる. 一般的に, 河口 砂州は, 大規模な出水時にフラッシュされるため, 河口 部の安全性は確保されるが, 砂州が完全にフラッシュし ないような河川では，河口部に発達した砂州を適切に管 理・制御していくことが重要となる.

砂州を管理・制御するためには，その形成・発達過程 および消失過程を解明することが有効な手段であり，い くつかの研究成果が報告されている，例えば，既往研究 1), 2)において，砂州のフラッシュによる地形変化および それにともなう水位変動について定量的に再現できるこ とが報告されており，砂州の消失過程について明らかに
されつつある. 一方，砂州の形成・発達過程については， 海域の波浪場と土砂移動のモデルを組み合わせた平面2 次元の数值モデルを用いて砂州の形成・発達を再現する 試みが行われ，その結果，ある一定の条件において砂州 の形成・発達過程を再現できることが報告されている3， 4). しかしながら, 数值解析で再現した砂州の形成・発 達過程と現地観測による結果を詳細に比較した例は少な い. また, 砂州の形成・発達は海域からの波浪および潮 位等に影響を受ける現象であり, 太平洋，日本海，瀬戸 内海沿岸などの河口が面している海域によって, その形 成・発達過程は異なる. そのため, それぞれの地域に応 じた形成・発達過程の解明が必要であるが，研究成果が 十分に報告されていないのが現状である.

本研究では, 日本海沿岸の若狭湾内に位置する由良川 河口部の砂州の形成・発達過程を明らかにするために, 詳細な砂州形状と波浪の現地観測を行い，その結果につ いて検討を行った. さらに, 由良川河口部に形成・発達 する砂州の再現計算を実施し, その形成・発達過程につ いて検討を行った. 


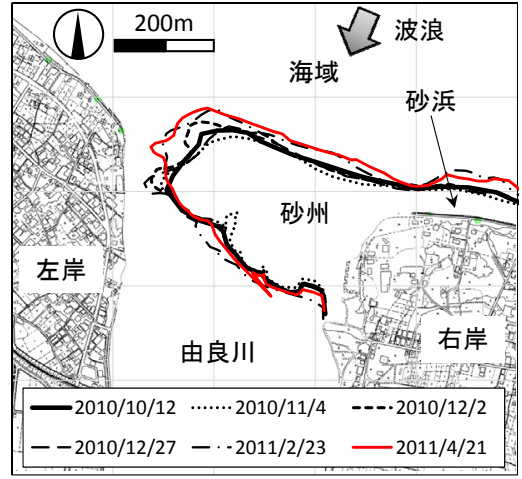

(a) 冬期(2010 11年)

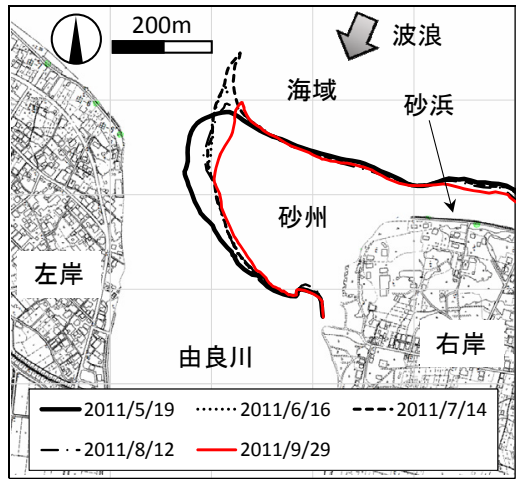

(b) 出水期および夏期(2011年)

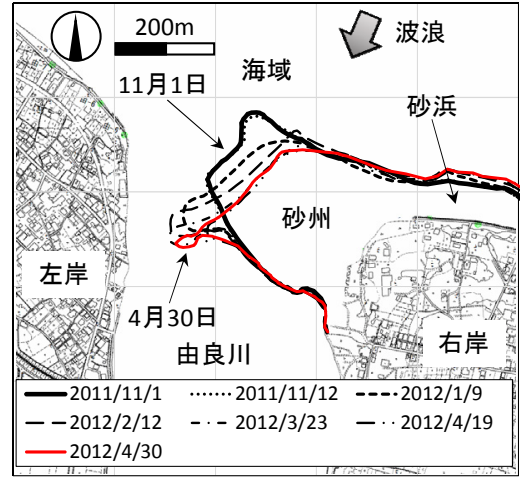

(c) 冬期(2011 12年)

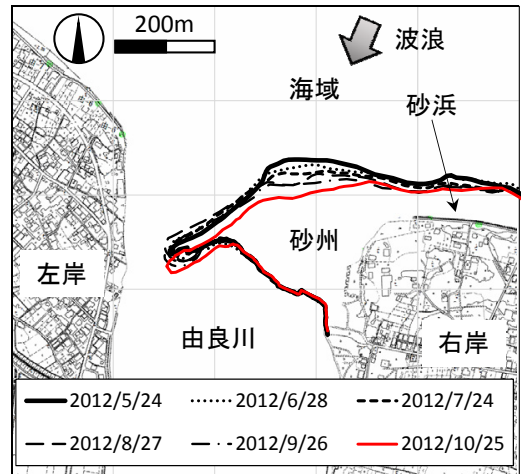

（d）出水期および夏期(2012年）

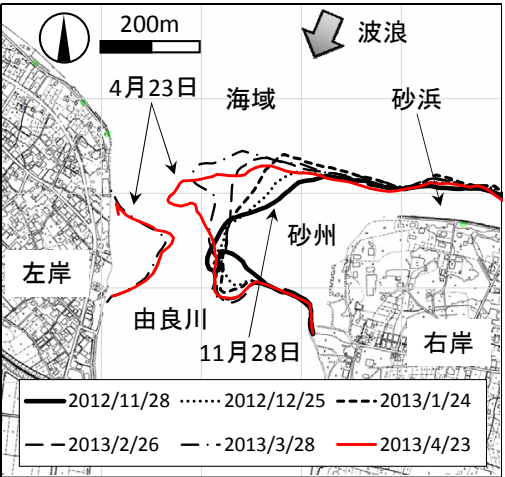

（e）冬期(2012～13年)

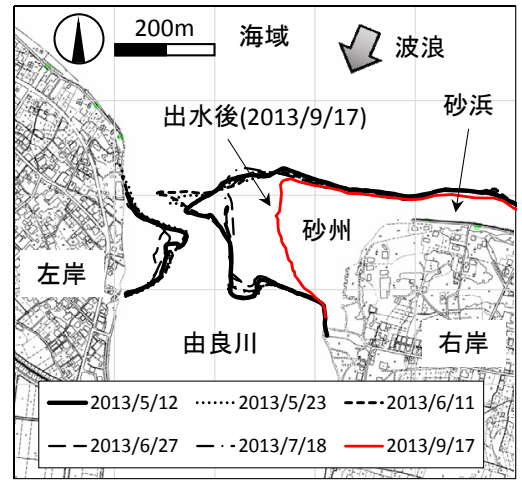

（f）出水期および夏期(2013年)

図-1＼cjkstart河口砂州形状の観測結果

\section{2. 由良川の概要}

由良川は流域面積 $1880 \mathrm{~km}^{2}$ の一級河川であり，その河 口部が京都府北部の若狭湾内に位置するような河川であ る. 河口部には，幅数百 $\mathrm{m}$ 程度の砂州が形成されており， その砂州の形状も毎年複雑に変化している. 近年では, 右岸側の砂州が大きく発達する傾向にあり，その影響を 受けて左岸側で砂州が消失し, 河岸が侵食され, 問題と なっている.

以上より, 由良川河口部における砂州の形成・発達過 程を把握し, 砂州の適切な管理・制御を行っていくこと が必要となるが，その発達・形成過程について明らかに されていないのが現状である.

\section{3. 現地観測}

\section{（1）観測方法}

現地観測は，由良川河口部に形成・発達する砂州の形 状変化と外力の関係を把握するために，両岸の砂州形状 と河口部に来襲する波浪を対象に実施した。

砂州形状の観測は，2010年10月～2013年9月の3年間に 約1ヶ月間隔で36回実施した。観測方法は，DGPS受信機 (GIR1600 SOKKIA製)を用いて砂州の汀線部位置の座標
を記録し，そのデータを整理した．現地観測1回の測点 数は90〜140点程度であり，約 $10 〜 20 \mathrm{~m}$ 間隔である.

波浪の観測は，2013年11月1日～2月17日の90日間実施 した．観測方法は，多機能型海象観測装置DL-2(株y ニック)を水深 $12 \mathrm{~m}$ 位置(緯度 $35^{\circ} 31^{\prime} 30.1^{\prime \prime}$ ，経度 $135^{\circ}$ $\left.17^{\prime} 33.6^{\prime \prime}\right)$ に設置し，水位変動，流速および波向の測定 を行った。観測結果は，1時間間隔の有義波高および周 期，波向に整理した.

\section{(2) 観測結果および考察}

\section{a) 河口部砂州の形状変化}

図-1は，由良川の河口部における1ヶ月単位の砂州形 状の観測結果を整理したものである. 図の上段(a), (c), (e)は冬期の10月〜翌年4月，下段(b)，(d)，(f)は出水期お よび夏期の5～9月の結果である. 図に示すように，観測 期間内では，砂州は右岸側で大規模に発達しており，幅 200～400m程度である. 困(b)のに示す夏期では，2011年 5月30日および9月21日に出水が発生し，右岸側の砂州の 面積が減少し，その後の図(c)に示寸冬期に砂州の形状が 変化している. 眓(d)の2012年の5～10月では，大規模な 出水が発生していないため, 砂州形状は変化していない

困(e)に示す2012年11月～2013年4月の冬期には，砂州 が大きく発達しており，3月には左岸側の砂州が新たに 形成されている. 由良川河口部では，1982～2001年頃ま で両岸に大規模な砂州が形成しており，左岸側の砂州は 2006年頃に消失し，今回の観測まで消失した状況であっ 

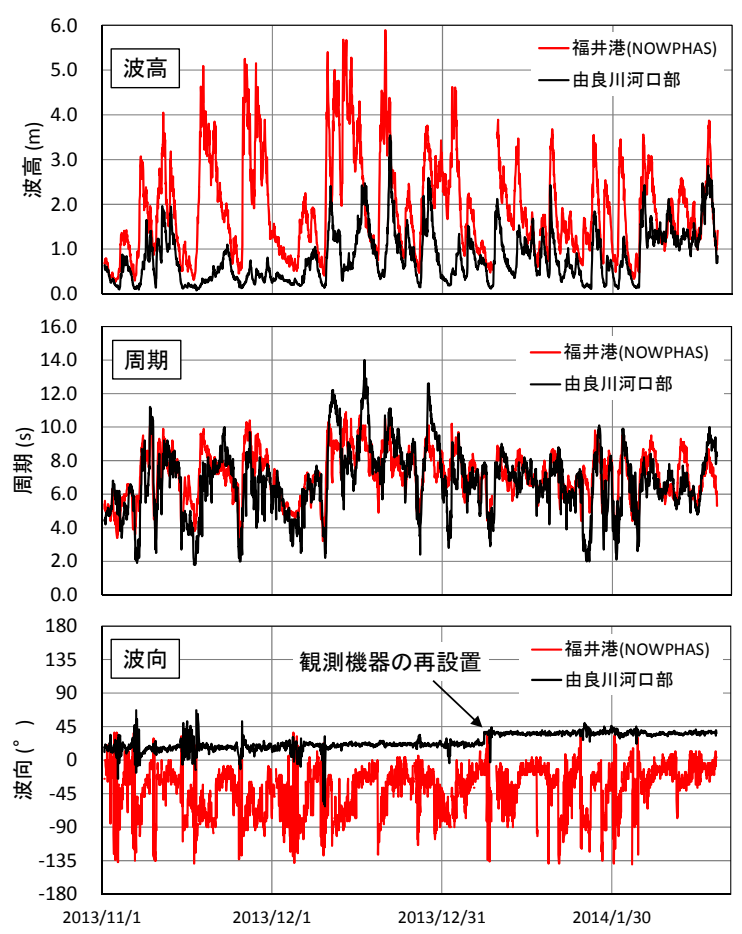

図-2 波浪観測結果(由良川河口部：水深12m)

た. 2001年以降では両岸に砂州が発達していたことから， この河口部では両岸に砂州が形成・発達しや寸い傾向が あると考えられる.ただし，その後，2013年9月15日に 発生した出水により, 左岸側の砂州がすべて消失し, 右 岸側の砂州も面積の半分が消失した.

砂州部の底質は，2006年の底質調査結果では，粒径 0.45 0.85mmが9割程度を占めている状況であった.

\section{b) 河口部の波浪状況}

図一2は，冬期に由良川河口部に来襲した波浪の観測結 果と若狭湾の外域に位置する福井港沖で観測された波浪 を整理したものである．福井港沖の観測結果は，全国港 湾海洋波浪情報網(NOWPHAS) $)^{5)}$ の結果である.

図に示すように，由良川河口部に来襲する波の波高は， 福井港沖の観測結果と比較して, 全体的に低い傾向があ る. 福井港沖の観測結果では，観測期間に波高 $5 \mathrm{~m}$ 以上 の高波浪が数回観測されているが，由良川河口部では， 大部分が波高 $2 \mathrm{~m}$ 以下であり，最大值でも波高 $3.5 \mathrm{~m}$ 程度 であった．この結果から，由良川河口部では，若狭湾の 外域と比較して来壟する波の波高は低く, 波高 $1 \sim 4 \mathrm{~m}$ 程 度の波で砂州が形成・発達していると考えられる.

波の周期は, 由良川河口部と福井港沖で大きな差はな いが，河口部では周期12s程度の比較的長周期の波が来 襲する傾向が見られる. 波向は, 福井港沖の観測結果で は，15〜-135 の間で変動しているが，由良川河口部で は全体的に $23^{\circ}$ 程度であり, 由良川河口部の海岸線とほ ぼ垂直の波向であった．ただし，1月7日に波向が若干変 化しているが，これは観測機器を点検のために再設置し た日であり，その影響であると考えられる。

c）砂州形状の変化と波浪の関係

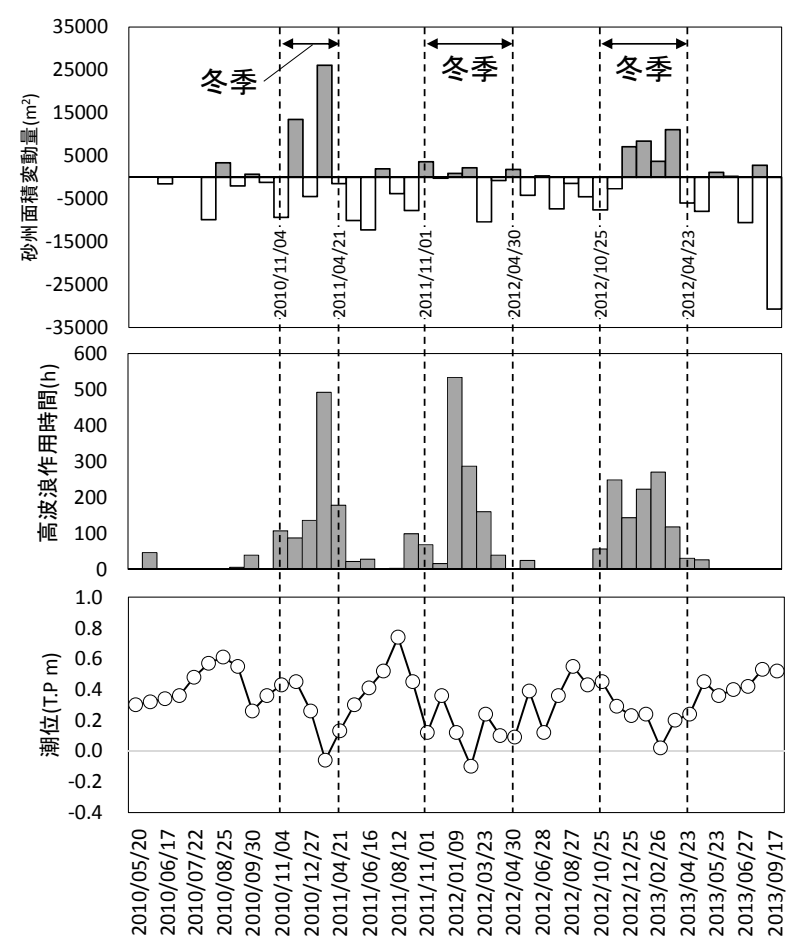

図-3 砂州の面積変動と外力 (波浪 - 潮位) の関係

図-3は，河口砂州の面積変動量，波高1.0m以上の波浪 が河口部に来襲した時間, 潮位の観測結果を整理したも のである.上図は1ヶ月間に変化した砂州の面積の変動 量を整理したものであり，中央の高波浪作用時間は，福 井港沖の波浪観測結果から由良川河口部の波浪を推算し， 波高1.0m以上となる時間を整理したものである．推算方 法については, 数值解析の部分に記述した. 下図は若狭 湾奥に位置する舞鶴観測点で観測された潮位である.

図に示寸通り，冬期に高波浪の作用時間が長く，砂州 の面積が増加している傾向があり, 出水期および夏期で 面積が全体的に減少している，ただし，2012年1月9日〜 3月23日までの期間では, 高波浪の作用時間は長いが, 砂州の面積は大きく変化していない傾向がある.これは, 図-1(c)に示寸ように，冬期の波浪の作用により，砂州先 端が河口側に押し込まれることで, 砂州の形状だけが変 化し, 海水面上にでている砂州の面積が変化していない ためである.

砂州面積と測定時の潮位の変動量を比較したものが上 段と下段の図である．現地観測では，砂州の汀線部を測 定しているため，観測結果が測定時の潮位に影響を受け ると考えられる. しかし, 図に示すように, 砂州の面積 変動は，潮位の変動傾向と一致しておらず，測定時の潮 位による砂州面積への影響は小さいといえる.

これらの結果より, 由良川河口部の砂州は, 冬期に砂 州が形成・発達しており, 夏期の出水によって消失・減 少する傾向があることが示された．これは，日本海沿岸 に位置する河口部の砂州形状の変動傾向と一致しており, 既往研究4)で報告されているように，冬期に来襲する波 浪が砂州の形成・発達に大きく影響しているためである. 
そこで，波浪場と土砂移動モデルを組み合わせた数值モ デルを構築し，砂州の形成・発達の再現計算を行い，そ の詳細な形成・発達過程について検討を行った.

\section{4. 数值解析}

\section{（1）計算モデルおよび基礎方程式}

計算モデルは，波浪場および河床・海底の土砂移動モ デルを組み合わせた平面2次元モデルである，海域の波 浪および海浜流の計算モデルは，修正ブシネスク方程式 モデルを使用した．基礎方程式は連続式と運動方程式で あり，式(1)〜(3)のようなものである.

$$
\begin{aligned}
\frac{\partial \eta}{\partial t}+\frac{\partial Q_{x}}{\partial x}+\frac{\partial Q_{y}}{\partial y}=0 & \frac{\partial Q_{x}}{\partial t}+\frac{\partial}{\partial x}\left(\frac{Q_{x}^{2}}{D}\right)+\frac{\partial}{\partial y}\left(\frac{Q_{x} Q_{y}}{D}\right)+g D \frac{\partial \eta}{\partial x} \\
= & \left(B+\frac{1}{3}\right) h^{2} \frac{\partial}{\partial x}\left(\frac{\partial^{2} Q_{x}}{\partial t \partial x}+\frac{\partial^{2} Q_{y}}{\partial t \partial y}\right) \\
& +B g h{ }^{3}\left(\frac{\partial^{3} h}{\partial x^{3}}+\frac{\partial^{3} \eta}{\partial x y^{2}}\right) \\
\frac{\partial Q_{y}}{\partial t}+ & \frac{\partial}{\partial x}\left(\frac{Q_{x} Q_{y}}{D}\right)+\frac{\partial}{\partial y}\left(\frac{Q_{y}^{2}}{D}\right)+g D \frac{\partial \eta}{\partial y} \\
= & \left(B+\frac{1}{3}\right) h^{2} \frac{\partial}{\partial y}\left(\frac{\partial^{2} Q_{x}}{\partial t \partial x}+\frac{\partial^{2} Q_{y}}{\partial t \partial y}\right) \\
+B g h & \left(\frac{\partial^{3} h}{\partial y^{3}}+\frac{\partial^{3} \eta}{\partial x^{2} \partial y}\right)
\end{aligned}
$$

ここで， $x, y$ は座標， $t$ は時間， $g$ は重力加速度， $\eta$ は水 面変動量, $Q_{x}, Q_{y}$ はそれぞれ $x, y$ 方向の線流量, $h$ は静 水面からの水深，Dは水面変動を考慮した水深，Bは定 数 $(=1 / 21)$ である.

河床・海底の土砂移動モデルは，既往研究6), 7)を参考 に，波動現象と流れによる土砂移動を計算できる三次元 海浜変形モデルを用いた. 波と流れによって移動する土 砂量の算定式を式(4)〜(6)に示す.

$$
\begin{aligned}
q & =q_{w}+q_{c} \\
q_{w} & =A_{w} F_{D}\left(u_{*_{m}}^{2}-u_{*_{c}}^{2}\right) u_{b} / g \\
q_{c} & =A_{c}\left(u_{*_{m}}^{2}-u_{*_{c}}^{2}\right) u_{c} / g
\end{aligned}
$$

ここで， $q, q_{w}, q_{c}$ はそれぞれ土砂フラックスの総量, 波による土砂フラックスおよび流れによる土砂フラック ス， $u_{*}{ }_{m}$ は波・流れ共存場の最大底面摩擦速度， $u_{*}$ は移 動限界摩擦速度， $F_{D}$ は土砂の移動方向を示す係数， $u_{b}$, $u_{c}$ は波による底面軌道流速振幅, 海浜流の断面平均流速 である， $A_{w}, A_{C}$ は，式(7)および(8)で算出される係数で ある。

$$
\begin{aligned}
& A_{w}=\frac{B_{w} \cdot w_{0} \sqrt{0.5 f_{w}}}{(1-\lambda) s^{\prime} \sqrt{s^{\prime} g D_{s}}} \\
& A_{c}=\beta \cdot A_{w}
\end{aligned}
$$

ここで， $w_{0}$ は沈降速度， $f_{w}$ は摩擦係数， $s^{\prime}$ は土砂の水中 比，入は土砂の空隙率， $D_{s}$ は土砂の粒径であり， $\beta$ は定 数である.

地形高の変化の算定は，地形勾配の影響を考慮した式 (9)を用いて計算を行った.

$$
\begin{aligned}
\frac{\partial z_{b}}{\partial t}= & -\frac{\partial}{\partial x}\left(q_{x}-\varepsilon_{s}\left|q_{x}\right| \frac{\partial z_{b}}{\partial x}\right) \\
& -\frac{\partial}{\partial y}\left(q_{y}-\varepsilon_{s}\left|q_{y}\right| \frac{\partial z_{b}}{\partial y}\right)
\end{aligned}
$$

ここで， $q_{x}, q_{y}$ は， $x$ 方向および $y$ 方向の土砂フラックス の総量， $z_{b}$ は局所的な地盤高， $\varepsilon_{s}$ は定数である.

（2）計算条件および境界条件

a) 計算ケース

計算は，2012年11月28日～2013年4月23日までの5ケ月 間における砂州の形成・発達過程の再現計算を実施した. 現地では，この期間に河口砂州が右岸側で大きく発達し ているとともに，左岸側では新たに形成されている.

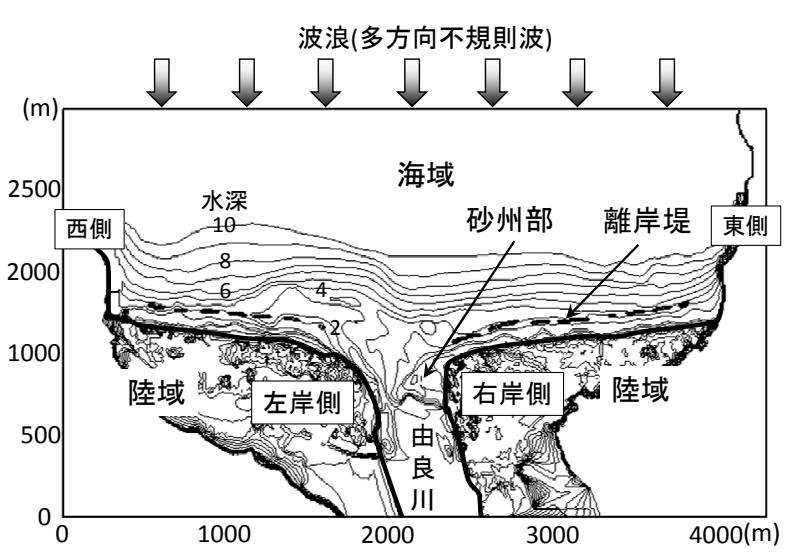

図-4 計算地形(由良川河口部) 
表-1＼cjkstart計算条件およびパラメータ

\begin{tabular}{|c|c|c|c|}
\hline \multicolumn{3}{|c|}{ 項目 } & 設定値 \\
\hline \multirow{4}{*}{ 計算 } & 計算領域 & $A x, A y$ & $\begin{array}{l}\mathrm{x} \text { 方向(沿岸距離) } 4300 \mathrm{~m} \\
\mathrm{y} \text { 方向(岸沖距離) } 2500 \mathrm{~m}\end{array}$ \\
\hline & 計算格子数 & $n x, n y$ & $\begin{array}{ll}\mathrm{x} \text { 方向(沿岸距離) } & 430 \text { 格子 } \\
\mathrm{y} \text { 方向(岸沖距離) } & 250 \text { 格子 } \\
\end{array}$ \\
\hline & 計算格子間隔 & $d x, d y$ & $\begin{array}{ll}\mathrm{x} \text { 方向(沿岸距離) } 10 \mathrm{~m} \\
\mathrm{y} \text { 方向(岸沖距離) } 10 \mathrm{~m}\end{array}$ \\
\hline & 計算時間間隔 & $d t$ & $0.1 \sim 1.0 \mathrm{sec}$ \\
\hline \multirow{3}{*}{$\begin{array}{l}\text { 波浪 } \\
\text { 計算 }\end{array}$} & 海底摩擦 & $n$ & $0.01 \mathrm{~m}^{2} / \mathrm{s}$ \\
\hline & 定数 & $B$ & $1 / 21$ \\
\hline & 重力加速度 & $g$ & $9.81 \mathrm{~m} / \mathrm{s}^{2}$ \\
\hline \multirow{7}{*}{$\begin{array}{c}\text { 土砂移動 } \\
\text { 計算 }\end{array}$} & 粒径数 & $n$ & 5粒径 \\
\hline & 粒径 & $D_{s}$ & $\begin{array}{c}0.075 \mathrm{~mm} 、 0.106 \mathrm{~mm} 、 0.250 \mathrm{~mm} \\
0.425 \mathrm{~mm}, 0.850 \mathrm{~mm}\end{array}$ \\
\hline & 土砂密度 & $\rho_{s}$ & $2650 \mathrm{~kg} / \mathrm{m}^{3}$ \\
\hline & 底質の空隙率 & $\lambda$ & 0.4 \\
\hline & $\begin{array}{c}\text { 無次元定数 } \\
\text { (波による土砂量) }\end{array}$ & $B_{w}$ & 0.07 \\
\hline & $\begin{array}{c}\text { 無次元定数 } \\
\text { (流れによる土砂量) }\end{array}$ & $\beta$ & 10 \\
\hline & 無次元定数 & $\varepsilon_{s}$ & 0.5 \\
\hline
\end{tabular}

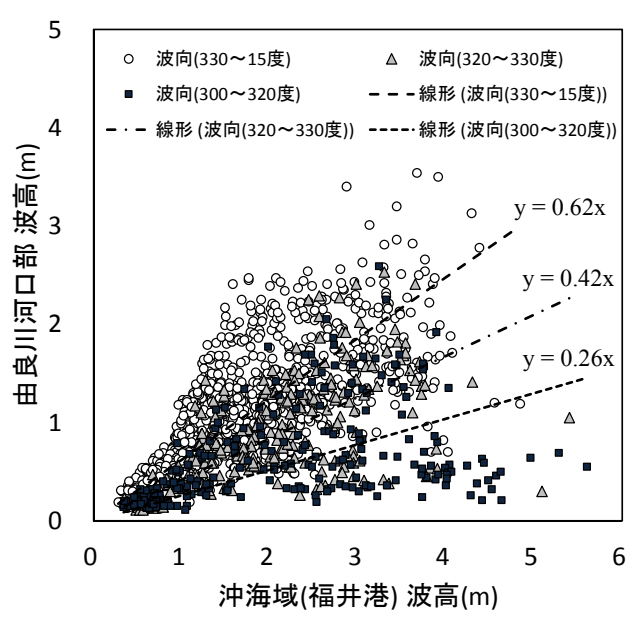

図-5 由良川河口部と福井港の波高

\section{b）計算条件}

計算地形は，図-4のような由良川河口部を中心とした 沿岸方向 $4300 \mathrm{~m}$ ，岸沖方向に $2000 \mathrm{~m}$ の範囲であり， 2012 年11月に実施した測量結果を用いて，海域および河口域 砂州部を作成した．土砂移動モデルに設定する底質の粒 径は，2006年に実施した底質調査で粒径0.85以下の成分 が9割以上を占めていたため，粒径 $0.85 \mathrm{~mm}$ 以下の底質を 対象に現地調査の粒径区分に合わせた5粒径を設定した。 計算全体の流れは，波浪および海浜流の計算を定常な状 況となるまで実施し，その結果を用いて4時間で移動す る土砂量を算出し，地形変化量の計算を行い，それを 5ヶ月間繰り返し行うものである．計算では，4時間で平 均化した波浪条件を作成し，1回の波浪が4時間継続する とモデル化して計算を行っている．計算に設定したパラ メータを表-1に示す。

\section{c) 入力波浪の設定}

造波条件は，沖側境界の水深 $12 \mathrm{~m}$ 地点において多方向 不規則波を設定した，入力した波浪条件は，由良川河口 部での波浪観測データがないため，福井港沖の波浪観測 結果から推算した波高および周期とした。波高および周 期の推算は，図-5に示寸ような波向別に整理した福井港
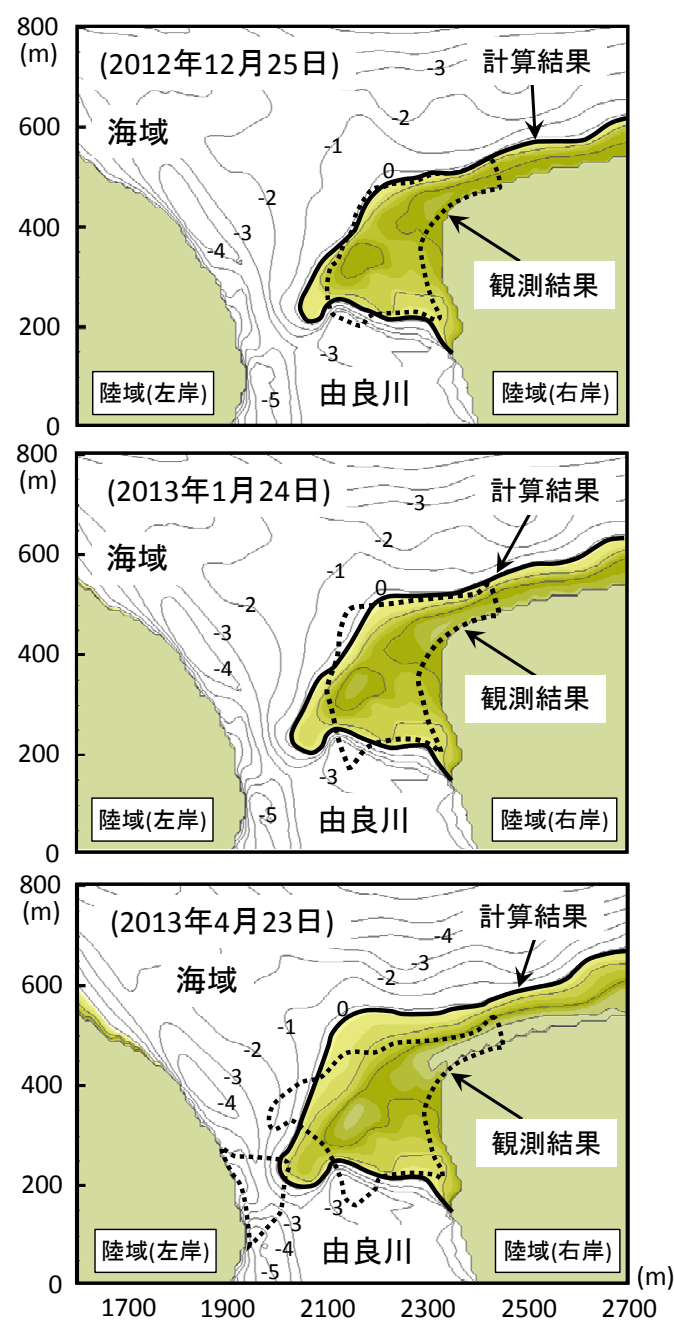

図-6 河口砂州の形成 · 発達過程の計算結果

沖と由良川河口部での波浪の関係を用いて行った．計算 では，推算して求めた由良川河口部の波高の時系列分布 を入力して計算を行った．ただし，現地観測結果の状況 から波高 $1 \mathrm{~m}$ 以下の波は，砂州の形成・発達に及ぼす影 響が小さいと考えられるため，波高1m以上の波を対象 とした。実際の計算では, 波浪を255ケース実施し, 1020時間に移動する土砂および地形変化の計算を行って いる. 波向は河口部の海岸線と垂直な $23^{\circ}$ を設定した.

\section{（3）計算結果および考察}

図-6は，由良川河口部の2012年11月28日～2013年4月 23日までの砂州の形成・発達過程を再現した計算結果を 示したものである. 図中の実線は計算結果，点線は観測 結果である. 図に示すように，2012年12月25日および 2013年1月24日の計算結果は，砂州の先端部分で違いは 見られるが，砂州の形状が観測結果とほぼ一致している. 砂州の先端では，砂州上を波が遡上し，河口上流側に土 砂を押し込むような現象が発生していると考えられるが， 数值モデルではそのような遡上による土砂移動が十分に 再現できていない，これは，今回使用している土砂移動 モデルが波による土砂の押し込み効果が卓越するモデル 


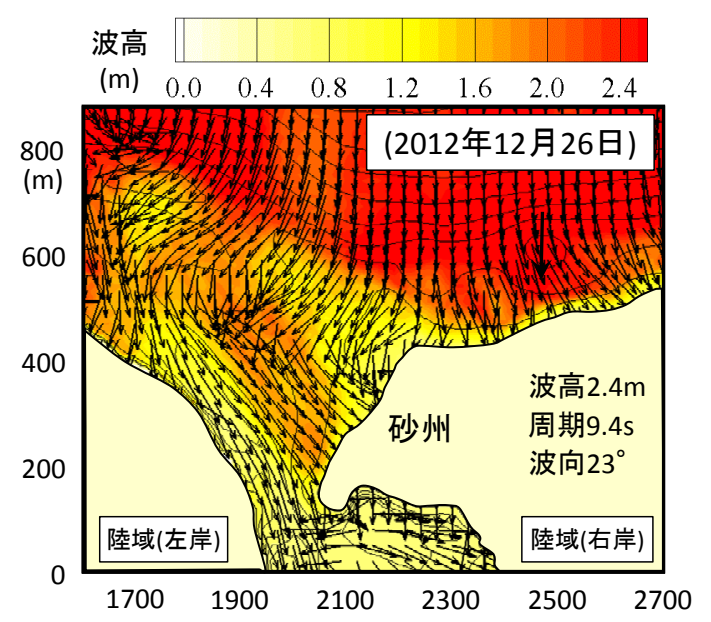

図-7 砂州周辺の波高および波向の計算結果

であるのに対して，遡上による土砂の移動は砂州上の流 れによって土砂が移動するためであると考えられる.

2013年4月 23日の計算結果では, 観測結果と比較して 海域側で砂州が過剩に堆積している傾向が見られる。 こ れは，数值解析モデルでは，波高が $2 \mathrm{~m}$ を超えるような 比較的激しい波浪条件の場合に，砂州が過剩に発達する 傾向にあることが原因である. 今回設定した波浪条件で は，波高 $2 \mathrm{~m}$ 以上の波が来襲寸る回数は，計算開始から 1 月24日まで期間で6回に対して, 砂州が過剩に堆積して いる2013年1月24日〜4月23日までの期間で26回であった。 高波浪時に砂州が過剩に発達する理由は詳細に把握でき ていないため, 波が遡上する場合の土砂移動の再現性と 合わせて今後の課題とした.

また，2013年4月23日の観測結果では，左岸側に砂州 が形成されているが，計算結果は砂州の形成が見られな い. 現地観測の左岸側砂州の発達位置は, 上流側からの 河川流と海域からの波が重なり合うような箇所であり， その両者の相互的な作用を考慮した計算を実施する必要 がある.ただし，今回の解析では，冬期の由良川の月平 均流量が30 $90 \mathrm{~m}^{3} / \mathrm{s}$ 程度であり, 砂州形状の変動に大き く影響を与えないものと仮定し, 河川流量を無視した条 件で計算を行った. そのため, 左岸側の砂州形成が再現 できなかったと考えられる.この点については，今後， 河川流の影響を考慮した計算を実施し，その影響を確認 することを予定している.

以上より，計算モデルにより2013年1月24日までの2ヶ 月間の砂州の形成・発達過程はほぼ再現できていたこと から，この期間において, 砂州の形成・発達過程の外力 となる砂州周辺の波浪状況について確認を行った.

図-7は，2012年12月26日に来襲した波の波高分布とそ の波向を示したものである. 境界位置での入射波浪は波 高 $2.4 \mathrm{~m}$, 周期9.4sであり，波向は計算領域にほぼ垂直に 入射する条件である，図に示寸ように，砂州の海域側で は，左岸側から斜めに右岸側一向う波向が卓越している ことがわかる.このような海域から砂州に向う波により，
砂州の海域側に堆積している土砂が，右岸側砂州の海域 側に押し込まれ，砂州が形成・発達していると考えられ る. また，12月26日以外の計算結果でも，波向の計算結 果はほぼ同様の傾向が見られた.

\section{5. 結論}

由良川河口部の砂州の形成・発達過程に関する検討を 行った. その結果，由良川の河口砂州は，冬期の波浪に よって形成・発達し, 夏期の出水によって一部が消失し ていることが確認された，本計算手法で，冬期の 2 ケ 程度の砂州の発達過程を再現でき, その結果から右岸側 砂州の形成・発達は, 砂州の海域側に堆積した土砂が波 によって右岸側に押し込まれることによって生じている ことが明らかになった。

ただし，今回の解析では，左岸側砂州が再現すること ができず，その形成・発達過程を明らかにすることはで きなかった. そのため, 今後, この点について検討して いく予定である.

謝辞 : 本研究の一部は, 国土交通省河川砂防技術研究開 発公募 地域課題分野(河川)(研究代表者 神田佳一, 2011～2013年度)の補助を受けて実施され，国土交通省 福知山河川国道事務所から貴重な資料の提供を受けた. 記して謝意を表します。

\section{参考文献}

1) 佐川拓也, 大谷靖朗, 市川真吾, 武内慶了, 山下武宣 : 河口 砂州フラッシュの再現計算と要因分析, 水工学論文集, 第51 巻, pp.955-960, 2007

2) 細山田得三, 田安正茂, Pujiraharjo Alwafi, 佐藤啓明 : 砂州 による洪水流下能力の低下と治水上の危険性評価に関する研 究一阿賀野川河口部を対象として一, 水工学論文集, 第51巻, pp.967-972, 2007

3) 川村育男, 田中 仁 : 鳴瀬川河口部における砂州地形変化機 構, 水工学論文集, 第51巻, pp.625-630, 2007

4) 細山田得三, 張瑞瑾, 星野雄亮 : 河口砂州の生成に及ぼす河 川水と海岸波動の影響に関する基礎的数值実験, 海岸工学論 文集，第52巻，pp.561-565，2005

5) 国土交通省港湾局 : 全国港湾海洋波浪情報網(NOWPHAS : Nationwide Ocean Wave information network for Ports and HArbourS), http://www.mlit.go.jp/kowan/nowphas/

6) 渡辺 晃, 丸山康樹, 清水隆夫, 榊山 勉 : 構造物設置に伴 う三次元海浜変形の数值予測モデル, 海岸工学講演会論文集, 第31巻, pp.406-410, 1984

7) 清水玩三, 山田晶子, 渡辺 晃 : 沿岸漂砂量の岸沖分 布と漂砂量係数, 海岸工学論文集, 第43巻, pp.571575, 1996

(2014. 9. 30受付) 